\title{
The Impact of Human Population on Biodiversity Conservation in Nigeria: The Need for Legal Intervention
}

\author{
Nelson Uwoh Sobere ${ }^{1 *} \quad$ Agent Benjamin Ihua-Madunenyi ${ }^{2 *}$ \\ 1.LL.B, LL.M, BL, Ph.D (in-view), Lecturer in the Department of Private and Property Law, Faculty of Law, \\ University of Port Harcourt, Rivers State, Nigeria \\ 2.LL.B, BL, LL.M (London), Lecturer in the Department of Commercial Law, Faculty of Law, University of \\ Port Harcourt, Rivers State Nigeria
}

\begin{abstract}
All over the world, human population size and growth have been forecast as a chief driver of biodiversity loss with no exception to Nigeria. Nigeria is universally known for its biodiversity of national and international importance but at the same time affected by its growing population. The Nigerian population is projected to grow above 195, 905, 783 by the middle of the century. No doubt, the health of the ecosystem has been irreversibly affected by the often quest to exploit the environment to meet the daily needs of the growing population. There is now more pressure on the components of biodiversity than ever before necessitated by the corresponding demand by humans. It is majorly human activities associated with population growth that cause the loss of biodiversity. Nigeria appears to have population control policy regulating the family size as per the number of children a household is expected to have but the policy appears to be voluntary and ineffective. Thus, there is the urgent need to slow down the population not only to reduce the pressure on biodiversity but also to ensure sustainable use of biodiversity for the benefit of the present and future generations. Therefore, this work seeks to examine the links between population growth and biodiversity conservation in Nigeria and the need to have an extant law to control the growing population. It makes far reaching recommendations which include the integration of family planning into biodiversity conservation. It also recommended that a legal regime should be put in place to regulate the family size of individual household with social and economic incentives outside population control policy that has no legal sanction.
\end{abstract}

Keywords: Impact, Population, Biodiversity, Conservation, Legal Intervention

DOI: $10.7176 / \mathrm{JLPG} / 92-16$

Publication date: December $31^{\text {st }} 2019$

\section{Introduction}

Man in accordance with the biblical dictates has been multiplying on earth without corresponding attempt to control it. ${ }^{1}$ The multiplication is also done with disregard to the fact that the earth is fixed and no further creation is ever expected but the ingenuity to sustainably use the resources of the earth for both present and future generations. This multiplication has eventually resulted to geometrical increase in human population. ${ }^{2}$ Before now, it has been projected that human-being would expand more than the available resources on earth, because the available land will be incapable of supporting an ever growing population. ${ }^{3}$ All over the global, population increase has been acknowledged as one of the indirect factors responsible for biodiversity loss in diverse ways. Nigeria is a country known for its biodiversity of both national and international importance. It is a biodiversity hotspot with levels of endemism and species richness comparable to anywhere in the world ${ }^{4}$. But indisputably, the abundance of the biodiversity has been severely threatened by the increasing population of the country. By 2050, Nigeria population is expected to be around 203.13 million. ${ }^{5}$ Because of the population, there is often the quest to exploit the environment which has irreversibly affected the health of the ecosystem with the resultant effect of biodiversity loss. There is now more pressure on the components of biodiversity than ever before necessitated by the corresponding demands by humans. ${ }^{6}$ The habitats are threatened with rapid destruction as a

* LL.B, LL.M, BL, Ph.D (in-view), Lecturer in the Department of Private and Property Law, Faculty of Law, University of Port Harcourt, Rivers State, Nigeria.

* LL.B, BL, LL.M (London), Lecturer in the Department of Commercial Law, Faculty of Law, University of Port Harcourt, Rivers State Nigeria.

1 Holy Bible, King James Version-Genesis 1:21

2 The current world population is estimated at 7.6 billion as of July 2018 according to the most recent United Nations estimation. It will definitely continue to increase in future. Available at www.worldometers.info.world-population [last accessed 15 February 2019]

3 Thomas Robert Malthus, An Essay on the Principle of Population, London, 1798. Available at https://www.gutenberge.org/ebooks/4239 [last accessed 7 January 2019]. See also Sam Ime Edet at el, Impact of Overpopulation on the Biological Diversity Conservation in Boki Local Government Area of Cross River State, Nigeria, American Journal of Environmental Engineering 4(5) (2014), p. 95 https://nigeria.wcs.org [last accessed 10 February 2019]

Taiwo Ogunmola-Omilani, Over-Population in Nigeria, Leadership Newspaper, August 18, 2017.

In recent time, nature conservation has been subjugated by the term biodiversity. However, the term biodiversity gained popular attention by the world media during the Earth Summit in Rio de Janeiro in the year 1992 which adopted the United Nations Convention on Biological Diversity. The Convention defines biodiversity to mean "The variability among living organisms from all sources including, 
result of pressure from growing local populations. ${ }^{1}$ Many scholars have argued for restrictions on population growth to protect the earth that 'this fixed world can only support a fixed population and that population growth must as a matter of necessity equal zero'. ${ }^{2}$ The wide spread loss of biodiversity has been ascribed to the regular increase in human population. ${ }^{3}$

Apparently, apart from population, there are other significant causes of biodiversity loss and extinction in Nigeria such as pollution, climate change, urbanization, gas flaring, invasive species, poverty, habitat destruction, deforestation etc. However, these factors are in my view interrelated and often reinforce one another thereby aggravating the loss of biodiversity. In any case, the other drivers manifest more with population explosion. In their inestimable numbers, various species and subspecies have become extinct every year accelerated by the uncontrollable human population. As it has been observed, "if present trends continue, we may destroy millions of kinds of plants, animals and microbes in the next few decades". 4

Generally speaking, biodiversity provides us with many benefits such as food, shelter, medicine, disaster control; climate regulation, income generation etc. yet human society continues to undermine this valuable resource base by prompting activities responsible for biodiversity losses ${ }^{5}$ and exacerbated by overpopulation. The present rate of biodiversity depletion in Nigeria is high than in early 70s and 80s. Thus, there is the urgent need to slow down the population not just only to reduce the pressure on biodiversity but also to ensure sustainable use of biodiversity for the benefit of the present and future generations. The paper however seeks to examine the links between population growth and biodiversity conservation in Nigeria and to see how the law has intervened in controlling the population as to halt the onslaught occasioned by human population on the ecosystem.

\section{Historical Background of Nigeria Population}

There is no accurate information on the exact population of the country but the population has been growing geometrically since the colonial period and the most significant increase witnessed in the recent years. ${ }^{6}$ Several attempts have been made right from the colonial period to the post-independence era to actually determine the population of the country for appropriate economic planning but were not fruitful. ${ }^{7}$ In a recent attempt in 1991 , the result was rejected particularly by leading figures in the South to have been rigged in favour of the North. The last of the recalled census was the one of 2006 which gave 140, 431, 790 as the estimated population of Nigeria. The Vice President of Nigeria- Prof. Yemi Osinbajo at the $5^{\text {th }}$ National Family Planning Conference in Abuja noted that "If Nigeria's prevailing annual population growth rate of 3.2 percent persists, we will have an additional 68 million people by 2030, and will be the third most populous country in the world by 2050 ". 8

It is however regrettable that right from the colonial period till now, no accurate census has been conducted to actually show the exact population of the country as the giant of Africa. A former chairman of the Nigerian Population Commission (NPC) had maintained that "no census has been credible in Nigeria since 1863 that even

inter alia, terrestrial, marine and other aquatic ecosystems and the ecological complexes of which they are part; this includes diversity within species, between species and of ecosystem".

See National Academy of Sciences, One Earth, One Future (1990)

2 Garrett Hardin, The Tragedy of the Commons, Journal Science (1968), p. 1243. See Also Paul R. Ehrlich, The Population Bomb, New York Times, (1970)

3 Causes of Recent Declines in Biodiversity: Rainforest Conservation Fund. Available at http://www.rainforestconservation.org/rainforestprimer/2.biodiversity.[last accessed 24 May, 2019]

4 William .P. Cunningham, Mary .Ann. Cunningham and Barbara Woodworth Saigo, Environmental Science: A global Concern, $9^{\text {th }}$ ed. (United States 2007), p. 237. See also Chauhan, B. S., Environmental Studies $1^{\text {st }}$ ed. (New Delhi 2011), p. 125

5 Swing Land IANR (2003), Capturing Carbon and Conserving Biodiversity: "The Market Approach," Earth Scan Publication. See also Emma Okafor, et al., Biodiversity Conservation for Sustainable Agriculture in Tropical Rainforest of Nigeria, New York Science Journal 3(1) (2010), p.83

${ }^{6}$ In 2017 , the total population in Nigeria was estimated at 190.9 million people. The population of Nigeria represents $2.35 \%$ of the world's total population which arguably means that one person in every 43 people on the planet is a Nigeria. Available at https://tradingeconomics.com/nigeria/population [last accessed 19 May 2019]. However, in 2018, the current population of Nigeria is 197, 713, 873 as of Monday, November 19, 2018, based on the latest United Nations estimates. It is said to be equivalent to $2.57 \%$ of the total world population. And Nigeria ranks number 7 in the list of countries by population. Available at www.worldometers.info/world-population/nigeria-population/[last accessed 19 May 2019]

${ }^{7}$ The first attempt began in 1866, when the colonialists organized a head count in what was then known as the Lagos Colony. A similar exercise was said to have been repeated in 1871, 1881 and $1901 .^{7}$ Another attempt at a national census was during 1952-53 which estimated Nigeria population at 31.6 million. ${ }^{7}$ This census has been considered an undercount for many reasons. ${ }^{7}$ Irrespective of its difficulties, the 1952 census has been generally seen as less problematic than any of its successors. This census was made during the colonial period and before the independence. After the 1952 census, subsequent attempts to conduct a reliable post-independence census have been stalled in controversy, and only one was officially accepted. The first attempt, in mid-1962, was cancelled after much controversy and allegations of over counting in many areas. The second attempt was in 1963, which was officially accepted but criticized for inaccuracy and manipulation for regional and local political purposes. The official figure was declared to be 55.6 million. Again, after the civil of 1967-70, an attempt was made to hold census in 1973, but the results were cancelled in the face of repeated controversy.

8 https://www.pressreader.com/nigeria/thisday/20181205/282136407485103 [last accessed 5 March 2019] 
the one conducted in 2006 is not credible." From 2006 till date, every attempt at conducting another census has been unsuccessful. But there has been noticeable increase in the country's population mostly through estimation. The National Bureau of Statistics estimated Nigeria population at 193.3 million. ${ }^{2}$ In the same vein, the United Nations recently estimated the population of Nigeria to be 197, 524, 968. It projected the population growth rate to be $2.57 \%$ of the world total population. ${ }^{3}$ The United Nations perceived that 'Nigeria population is set to overtake US'4 and also that 'Nigeria's population will grow up to 399 Million by 2050 '5. Indisputably, other drivers of biodiversity loss are linked to increase in human population. Thus, if the ever increasing human population is not controlled, life will be miserable and particularly for the future generations as the available biological diversity resources will not measure with the geometrical population increase to be witnessed.

\section{The State of Biodiversity in Nigeria}

Nigeria is not an exception to the looming contemporary environmental problem of loss of biodiversity. Among the countries of the world, Nigeria is a country gifted with a range of animal and plant species. ${ }^{6}$ In an earlier report made available by the repealed Federal Environmental Protection Agency (FEPA) of Nigeria in 1992 ${ }^{7}$, it shows that Nigeria holds a variety of biodiversity ranging from plants, animals, insects, reptiles, fishes, birds, microorganisms and amphibians. ${ }^{8}$. In fact, the report recognized the forests in Cross River State of Nigeria to be a hotspot for amphibian biodiversity. ${ }^{9}$ In a subsequent report in 2010 , certain numbers of vertebrate and invertebrate, insects, birds, fish, mammal and reptile species were identified in Nigeria ${ }^{10}$.

The country is also identified as a global hotspot for primate species with high number found in the Gulf of Guinea forests, though endangered, with less individuals found in few protected areas of Cross River State of Nigeria. ${ }^{11}$ In the same vein, there is variety of many crops species that were originally cultivated in Nigeria and now spreading all over the world such as sorghum (sorghum bicolor), cowpeas (Vigna Unguiculata), West African Rice (Oryza Sativa), Yams (Dioscorea Spp), Bambara groundnuts (Vigna Subterranea) etc. However, countless of these crops have been lost out in favour of more "modern" cultivated crops ${ }^{12}$ (Invasive species). Many of the Nigerian endowed animal and plant species have been included in the IUCN Red List of globally threatened species of which some are classified as endangered and critically endangered. ${ }^{13}$

For Nigeria, the survival of the present and future generations are somewhat linked the abundance of biodiversity resources because of the benefits derived from it in terms of food provisions, housing materials, income generation, job opportunities, fuel etc. Conversely, despite the efforts targeted at reducing its loss, biodiversity is still facing numerous irreversible threats thereby reducing the level of reliance placed on it by man. ${ }^{14}$ There is uncommon destruction of the terrestrial ecosystems which covered the majority of the plant and animal species. This is also true for inland water ecosystems as well as wetlands, and highly valuable marine and coastal ecosystems which have long been diminishing. ${ }^{15}$ Indeed, these biological wealth are today extremely impacted by emerging human activities actuated by increase human population. ${ }^{16}$ Biodiversity loss is now one of the major concerns of our time. Nigeria's rich and varied biological diversity is fast disappearing and exposed to a variety of threats worsen by human growing population.

https://www.tribuneonlineng.com/88207/ [last accessed 5 March 2019]

Ojo Ebenezer, "Nigeria's Population Now Estimated at 193.3 Million". https://234today.com/2017/12/nigerias-population-nowestimated-193-3million $>$ [last accessed 7 March 2019]. See also The Nation Newspaper of 6 December, 2017. According to the recent United Nations Department of Economic and Social Affairs, Nigeria has been projected to add no fewer than 189 million people to its population between 2018 and 2050. Available at https://www.vanguardngr.com/2018/nigeria-add-189m-people-2018-2050-UN [last accessed 24 May 2019]

https://www.google.com/search?q=current+population+of+nigeria\&ie=utf-8\&oe=utf [Accessed 20 May 2019]

Available at Nigeria Television Authority (NTA) 7PM Headline News of 30 July, 2015.

Available at African Independent Television (AIT) 8AM Headline News of 31 July, 2015

Nigeria Biodiversity and Tropical Forestry Assessment, USAID/NIGERIA, June 2008, p. 1. See also Nigeria First National Biodiversity Report, July 2001, P.3

It is now replaced by the National Environmental Standards and Regulations Enforcement Agency (NESREA) by virtue of the NESREA Act, 2007 that repealed FEPA Act, 1992.

8 See the Federal Environmental Protection Agency Report, (FEPA) 1992.

9 The concept of hotspot was first developed by Russell Mittermeier in 1988, as a way to prioritize conservation. Biodiversity hotspots are areas that support natural ecosystems that are largely intact and where native species and communities associated with these ecosystems are well represented. Available at www.environment.gov.au/biodiversity/... [last accessed 20 May, 2019]

10 See The Nigeria Fourth National Biodiversity Report, (NFNBR), 2010

11 Nigeria National Biodiversity Strategy and Action Plan (2003) P.10

12 Nigeria Biodiversity and Tropical Forestry Assessment, op cit, P.15.

13 Ibid

14 Traditional medicines derived from plants are relied upon by a greater proportion of the populations. Herbal medicines are routinely administered at home to more than half of children suffering from common ailments such as fever, malaria, headache etc.

15 CBD CoP, 2010

16 P.C. Aju and I..O. Ezeibekwe, Understanding and Appreciating the Need for Biodiversity Conservation in Nigeria, Journal of Medicinal Plants Research 4(24) (2010) Pp. 2605-2608. <http://www.academicjournals. org/JMPR DOI:10.5897/JMPR09.100> [ last accessed 9 June, 2019] 


\section{The Links between Population and Biodiversity Conservation}

No doubt, man inhabits the earth with other creatures such as plant and animal species. Therefore, there is a great relationship between man and his immediate environment. As population increases, the environment is impacted by diverse human activities ultimately leading to loss of biodiversity. There is no refuting that increase in human population affects the ecosystems that form part of the environment. On the other hand, as population increases, the demand for biological resources also increases. ${ }^{1}$ Thus, there is distortion of the natural balance of the ecosystem. ${ }^{2}$ When there is an increase in households' numbers, it affects the level of biodiversity conservation. ${ }^{3}$ Population is as an essential factor indirectly leading to the loss of species. ${ }^{4}$ Other drivers of biodiversity loss such as urbanization, deforestation, climate, reclamation, overexploitation, etc. are on the increase because of the uncontrollable human population. This is particularly true in case of Nigeria where a greater number of the population is characterized with poverty forcing them to place more reliance on the immediate environment for survival. ${ }^{5}$ The links between population and biodiversity loss in Nigeria cannot be over emphasized. Some of which are:

\section{(i) Habitat Loss}

Habitat is the home for biodiversity. As population increases, the habit is impacted. Habitat destruction is one of the greatest drivers of biodiversity loss. It has a direct link with human population increase. Loss of habitat is more witnessed in an area where population is high and most areas rich in biodiversity are prone to high population levels. ${ }^{6}$ Agriculture, housing, urbanization, and industry are destroying the habitants of many plants, animals and microbes. Habitat loss is an important cause of known extinctions directly associated with human population. This is factual in Nigeria where in the same vicinities, human beings and species are in high concentration. In this situation, the degree of threat to the existing species is bound to be high resulting from their distorted habitat. ${ }^{7}$ In Nigeria, there is intense expansion of land for agriculture following the increase in human population. Lands which are hitherto pristine with its known biodiversity have now been encroached for agriculture. Thus, human activities have irreversibly impacted key habitats like forests, grasslands and coastal zones leading to loss of species that originally inhabit them. ${ }^{8}$

By habitat destruction, it is those species that are local, endemic, or which have specialized habitats that will be more susceptible to extinction, since once their localized habitat is destroyed or transformed for human use, they will be wiped out ${ }^{9}$. For instance, two major birds' species that inhabit the Obudu and Mammbilla Plateus are threatened due to the loss of their patches in the forests. ${ }^{10}$ It has been discovered that degraded forest areas has been the major cause of decline in the population of chimpanzee in the south-west area of Nigeria. ${ }^{11}$ In the future, habitat loss will be the most recorded cause of biodiversity extinction crisis ${ }^{12}$ worsens by the geometrical progression in the country's population ${ }^{13}$.

\section{(ii) Urbanization}

The development and growth of a city has a direct link with human population. It is indisputable that urbanization instigated decline in biodiversity and in some cases go into extinction. With growing of cities, healthy habitats are damaged or disjointed into patches and no more sustainable for ecological existence. In this regard, species that originally inhabits the impacted areas are prone to destruction even leading to their extinction. Some encountered wetlands ${ }^{14}$ are reclaimed and hotspots ${ }^{1}$ destroyed for the purposes of construction and

1 William N. Ryerson, Population, the Multiplier of Everything Else, in Richard Heinberg and Daniel Lerch (eds.), The Post Carbon Reader: Managing the $21^{\text {st }}$ Century's Sustainability Crisis, California 2010, Pp. 2-3.

2 Paul. R. Ehrlich and Anne. H. Ehrlich, The Population Bomb Revisited, The Electronic Journal of Sustainable Development, 1(3) (2009), p. 66.

3 Jianguo Liu et al, 2003 Effects of Household Dynamics on Resource Consumption and Biodiversity, Nature (2003), p. 421.

4 Cincotto and Gorenflo 2011, Millennium Ecosystem Assessment (MA) 2005. Ecosystems and Human Well-Being, Biodiversity Synthesis, Washington DC, World Resources Institute (WRI)

5 Nigeria is said to be the poverty capital of the world. It is shown that about 86.9 million Nigerians are now living in extreme poverty of its estimated 180 million population. Available at https://qz.com/Africa/1313380/nigeria-has-the-highest-rate -of-extreme-poverty-globally [last accessed 6 July, 2019]

6 Cincotto, R.P and R.Engelman, 2000, Natures Place: Human Population and the Future of Biological Diversity, Washingto DC: Population Action International.

7 The UN's World Population Prospects 2017 stipulates that Nigeria's current population of 189.59 million, the seventh largest, will exceed 300 million by 2050 to become the world's third largest after India and China, displacing Indonesia, the United States and Pakistan. Available at https://punchng.com/managing-nigerias-population-for-growth/ [last accessed 20 May 2019]

Millennium Ecosystem Assessment, 2005

https://www.rainforestconservation.org/rainforest-primer/2-biodiversity[Accessed 20 May, 2019]

Nigeria Biodiversity Tropical Forestry Assessment, op cit, p. 36

1 JElizabeth J. Greengrass, A Survey of Chimpanzees in South-West Nigeria: NCF-WCS Biodiversity Research programme, (2006), p. 35

12 Cause of Recent Declines in Biodiversity, "Rainforest Conservation Fund". Available at http://www.rainforestconservation.org/rainforest-primer/2-biodiversity. [last accessed 24 May, 2019]

Emphasis mine.

14 Wetlands include areas of "marsh, fen, peatland, or water, whether natural or artificial, permanent or temporary, with water that is static or flowing, fresh, brackish or salt, including areas of marine water the depth of which its low tide does not exceed six metres. 
development. $^{2}$ According to the United Nations, about $55 \%$ of the world's population today lives in urban areas/cities and is expected to increase to $68 \%$ by 2050 with 2.5 billion people to be added ${ }^{3}$. As it was observed by Peter Kareiva that: ${ }^{4}$

As a species we have lived in wild nature for hundreds of thousands of years, and now suddenly most of us live in cities-the ultimate escape from nature. If we do not learn to build, expand and design our cities with a respect for nature, we will have no nature left anywhere. $8 \%$ of vertebrate species have been labeled as 'endangered' due to the effects of rapid urban development. That number may continue to rise with new urban expansion and growth. ${ }^{5}$

In Nigeria, urbanization has greatly impacted the environment in many ways. Most of the existing wetlands are reclaimed for development destroying the species that lives in them. During construction, wetlands are destroyed and irreversibly leading to direct loss of habitat ${ }^{6}$. With the rate at which cities are growing now, critical habitats and sites of conservation concern are under serious threat. With the existing 36 States of the Federation and the capital territory Abuja, there is no gainsaying that urbanization has step up tremendously in the country. As a result of urbanization, large portion of the Lekki Peninsula (an important mangrove and low land swamp forest habitat for many threatened hydrophilic species) has been reclaimed to provide for the increasing population Lagos, Nigeria. Abuja, the capital city of Nigeria is not an exception. It has been argued that in Enugu, the capital city of Enugu State, Nigeria that the population pressure exerted through urbanization has created different environmental problems such as deforestation in an unprecedented manner and therefore reduces the benefits derived from biodiversity. And that urbanization indeed caused loss of habitats, death of native species, endangering and threatening of the existing local species of the area. ${ }^{7}$ As was commented by Ronald McDonald that:

While we found the effects of urbanization to be localized, cumulatively, they pose a big threat to biodiversity. Our urban footprint covers much of the globe and is coming closer to stomping out many endangered species and posing new risks to protect areas and parks. ${ }^{8}$

Also, the existing parks are now affected by encroaching development. There is obvious residential and commercial construction beyond the boundary and close to the parks causing serious threats to the species that inhabit the parks. It appears more priority is placed on development to meet the need of the growing population than on the conservation of biodiversity that holds our survival. ${ }^{9}$ As human beings are competing for the same land reserved for other creatures, wild animals are losing their habitats As a result, the populations of wildlife species in the parks are being reduced. The future of the parks remains precarious, particularly because current policies seem to propagate urbanization with scarce regard its protection. Hardly any of the protected areas remains untouched, with over $90 \%$ of it bearing some evidence of damaging human activities. As was noted by kendall Jones of University of Queensland that "A well-run protected area network is essential in saving species. If we allow our protected area network to be degraded, there is no doubt biodiversity losses will be

According to Article 1 of the Ramsar Convention of 1971, Wetlands are important habitat for fauna and flora and especially as waterfowl habitat. Land degradation affects important eco-systems, such as wetlands causing loss of habitat for birds and other animal and plant species. They are found in all ecological zones of Niger Delta freshwater zone and other river floodplains in Nigeria. Some of the wetlands have been designated with International Importance. For example, the Nguru Lake and Marma Channel Complex have been designated as Wetland of International Importance. The Nguru Lake has the international site No: 1039 of 2 October, 2000.

1 Hotspots are biologically rich areas with high diversity and a large percentage of endemic species. The term was introduced by Myers in the year 1988. According to Myers et al (2000), an area is designated as a hot-spot when it contains at least $0.5 \%$ of the plant species as endemic. See www.conservation.com; B.S. Chauhan, op cit, p. 113. The Niger Delta Region of the country (Nigeria) has been described as biodiversity hotspots. Most of the animal and plant species endemic to the region have gone into extinction as a result of oil exploration in the region since 1956. Due largely to Multinational oil companies exploration activities in the region and coupled with incessant oil pollution and gas flaring, the area has divested of its known biodiversity richness and abundance.

2 In the United Kingdom for example, an increasing human population density, and the resulting increase in urban development were found to be the cause of $35 \%$ of scarce plant species extinction in the country's surrounding urbanized areas. Similarly, in the United States, Urbanization has been found to be directly responsible for the endangerment of 275 species, only invasion by non-native species had a greater impact causing 305 species to become endangered. Available at www.ecologicablog.wordpress.com/.../how.do.-[Accessed 24 May, 2017]

Available at https://www.un.org/development/ [last accessed 7 July, 2019]

Available at www.science-daily.com/.../-[last accessed 16 March, 2019]

Peter Kareiva is the Chief Scientist at the Nature Conservancy and Co-author of the report.

Ajibola, M.O, B.A. Adewale, B. A. and Ijasan, K.C., Effect of Urbanization on Lagos Wetlands, International Journal of Business and Social Science 3(17) (2012), Pp. 310-31.

7 Emodi Friday and Edmund. Emeka, Assessment of Urbanization as it affects Biodiversity in Enugu, Nigeria, Journal of Ecology and Environmental Sciences 6(2) (2018), p. 78

8 Available at www. sciencedaily.com- [last accessed 24 May, 2019]

9 In recent time, there has been a serious threat to the wildlife of Cross River National Park as a result of a superhighway project embarked upon by the Cross River State government which attracted protest from local communities and international attention. It is a home of various species of both national and international importance. 


\section{exacerbated". 1}

\section{(iii) Deforestation}

The natural forests are the collection of biodiversity. All over the world, households and industries derived some benefits from the forests. Forests provide man with inestimable services on daily basis. Our existence is somewhat dependent on availability of natural forests ${ }^{2}$ but today they are being destroyed ever than before due largely to increase in human population. More than a half of the animals and plants species live in the tropical forests ${ }^{3}$. It has been observed that 'if the current rate of deforestation continues, the world's forests will vanish within the next 100 years causing unknown effects on global climate and eliminating the majority of plants and animals species on the planet'. ${ }^{4}$

In Nigeria, deforestation is a continuous process because of the economic benefits the increasing population derived from the forest ecosystem. No doubt, modern agricultural practices have intensified the rate of deforestation in Nigeria ${ }^{5}$. Deforestation is a direct cause of biodiversity loss. About $85 \%$ of domestic energy use is derived from the forest ${ }^{6}$. This is aggravated by the fact that the unsustainable timber cuts are not replaced to fill the gap and has made the forest to appear empty and lack of resilience. The savannah and rainforest ecosystems are victims of high depletion of fuel wood species. ${ }^{7}$ The Nigerian tropical forests are hard hit. Nigeria has the highest deforestation rate in the world ${ }^{8}$. This is likely to increase with the rising rate in the country's population. Deforestation threat is a common phenomenon in Nigeria and particularly in the Niger delta region. ${ }^{9}$ In most of the local communities where you have more of the forests, it is very unlikely to drive along any road without seeing stacks of fuel wood displayed for sale that is devoid of endangered species. ${ }^{10}$

\section{(iv) Over-Exploitation/Harvesting}

This is the harvesting of wildlife to the point of diminishing returns. Over exploitation by humans causes massive destruction to natural ecosystems. There is no gainsaying that every year, hundreds of millions plants and animals are caught or harvested from the wild and then sold as food, pets, ornamental plants, leather, tourist curios, gums, fruits, nuts, dyes, cane graft and medicine etc. It is correct to say that while a good number of this trade is legal and is not harming wild populations, a worrying great proportion is illegal-and threatens the survival of many endangered species ${ }^{11}$. This tends to increase as human population increases. Overexploitation is seen as being the second largest direct threat to many species after habitat loss, and this has prompted the WWF (the World Wide Fund) to tackle illegal and unsustainable wildlife trade as a priority. ${ }^{12}$

It is not in doubt that greater proportion of Nigeria's population is concentrated in the rural areas where unsustainable use of biodiversity and forest products is the norm ${ }^{13}$. Most people in the rural areas depend substantially on extraction of resources from the wild in form of nuts, fruits, seeds, ropes, dye, gum, wax, honey, etc. which constitute a huge resource for food, medicine and commercial ${ }^{14}$. But due to human pressure, the forest has been degraded to a less productive level ${ }^{15}$. On the contrary, these products are uninterruptedly being sourced from the wild, thereby reducing the availability of the species and threatening their existence ${ }^{16}$. The rate of unsustainable use of other non-timber forest products is now a challenge in Nigeria. ${ }^{17}$ As population increases,

Available at https://www.independence.co.uk/environment/national-parks-wildlife-sanctuaries-threatened-by-human-activiyies [last accessed 23 June, 2019]. Also Available at https://www.sciencedaily.com [last accessed 23 June 2019].

2 The benefit of forests cannot be over emphasized this is because forests provide food for man, timer and non-timer products, medicine, income, aesthetic value, regulation of disaster and climate etc.

Available at www.en.wikipedia.org/wiki/deforestation- [last accessed 23 May, 2019].

B.S. Chauhan, Environmental Studies $1^{\text {st }}$ edu (New Delhi, 2011), Pp. 21-22.

For example, the introduction of cash crops like cocoa, coffee, rubber, cotton, groundnut and oil palm into the farming systems since the 1900s was a big impetus for massive deforestation of the natural ecosystems. The land devoted to agriculture increased from 8.9 Million hectares in 1951 to about 55.8 Million hectares in 1995. Between 2000 and 2005, Nigeria lost 55.7 percent of its primary forests due to logging, agricultural expansion, and fuel wood collection and this is bound to increase along with the population explosion currently witnessing in the country. The recent rice farming programme in some of the Niger delta states of the federation has also resulted to the deforestation of several forest serving as habitats to many of the Nigerian biodiversity of national and international importance. The massive rate of deforestation is a direct cause of biodiversity loss.

6 The Fourth National Biodiversity Report, 2010, p. 24

Ibid

This is according to the United Nations Food and Agricultural Agency (FAO) Report, 2005. The Report was corroborated by recent African Independent Television (AIT) 8pm News of 5/6/16 where the FAO observed that Nigeria is the second known country for deforestation in the world.

9 For instance, during the World Environment Day, 2016, the Bayelsa State of Nigeria Environmental activist warned at the rate in which Irvinga Gabonensis otherwise known as "Ogbono" trees are cut down and wants the tree protected because of its peculiar economic benefit to the people". The tree is now considered as endangered species in the area and is said to be facing extinction?.

Nigeria Biodiversity Tropical Forestry Assessment, op cit, p. 36

Available at wwf.panda.org $>$ Home $>$ Our Earth $>$ Species $>$ Species Threats-[last accessed 24 June, 2019]

Ibid

See www.encapafrica.org [ last accessed 7 July, 2019]

${ }^{4}$ See Nigeria Fifth National Biodiversity Report, (2015), 22

15 Ibid

${ }_{16}^{16}$ Ibid

${ }^{17}$ Nigeria Biodiversity and Tropical Forestry Assessement, op cit, p. 36 
overexploitation is bound to increase until there is no appreciable level of forests' resources left to be harvested. There is an identified increase in the harvesting and trade of wild animals and plants. Millions of birds' species are exported out of Nigeria yearly. In most markets in Nigeria, there is a display of varying huge animal skins and parts. Likewise orchids and many other ornamental plants are harvested to meet overseas demand ${ }^{1}$.

\section{(v) Widespread Poverty}

There is no doubt that as population increases, the level of poverty will also increase and this has a direct impact on biodiversity conservation. There is a significant connection between poverty and biodiversity with abundant of the biodiversity occurring in some of the poorest populated countries of the world ${ }^{2}$. Poverty is a common phenomenon all over the globe and particularly in developing countries such as Nigeria. Poverty is essentially linked to ecosystem deterioration which ultimately leads to loss of biodiversity ${ }^{3}$. Greater number of the population lives in areas of high biodiversity, who depend on it for food, health, income and general livelihood. ${ }^{4}$ With the increased rate of poverty in the growing population, the sustainable use of the available plant and animal species is not guaranteed. And because of the associated problems of biodiversity loss and poverty, conservation and poverty reduction ought to be tackled together ${ }^{5}$. It is conceived that available resources could only cope with the needs of a controlled population size. When the population is controlled, the human pressure exerted on the species as result of extreme poverty will definitely reduce.

Nigeria is a country rich in biodiversity ${ }^{6}$ and at the same time enmeshed in wide spread poverty. Nigeria's comparative poverty size stood at $54.4 \%$ in 2004 and in 2010 increased to $69 \%{ }^{7}$ and is likely to increase higher in the future. ${ }^{8}$ At the end of 2018, 90.8 million Nigerians out of the estimated 195.6 million people were said to be living in extreme poverty ${ }^{9}$. In a recent report, Nigeria is said to be the poverty capital of the world ${ }^{10}$. Wildlife is seen as nature's gift for survival in Nigeria ${ }^{11}$. It is obvious that not much can be achieved for sustainable development if the rate of poverty lurking the nation particularly the rural dwellers is not tackled now. As it was observed:

Poverty pollutes the environment, creating environmental stress in a different way. Those who are poor and hungry will often destroy their immediate environment in order to survive. They will cut down forest; their livestock will overgraze grasslands; they will over use marginal land; and in growing numbers, they will crowd into congested cities. The cumulative effect of these changes is so far reaching as to make poverty itself a major global scourge ${ }^{12}$.

\section{(vi) Wetland Reclamation.}

As population increases, there is more promising of wetlands reclamation. Nigeria and particularly the Niger delta region of the country are known for wetlands as habitat for aquatic resources. The varieties of species of the wetlands are inestimable. Wetland is a home of many species including reptiles, amphibians, mammals and birds $^{13}$. These species live, breed and feed within the wetlands and the destruction of the wetlands is tantamount to their loss. It is contended that apart from the overexploitation of the wetlands, they are increasingly disappearing as a result of unprecedented reclamation actuated by increase in human population in terms of development and infrastructure ${ }^{14}$. Some of these species especially the birds are endemic to Nigeria and the moment they go into extinction, they cannot be recovered again. Wetlands are the life-enhancing systems of the environment. ${ }^{15}$ Thus, the loss of the wetland (their natural habitat) will affect their survival. Because of the

Muhammed.Tawfiq Ladan, Natural Resources and Environmental Law and Policies for Sustainable Development in Nigeria, Nigeria, Zaria 2014, p. 80 .

https://www.reserachagte.net/publication/222826477-poverty-and -biodiversity-measuring-the-overlap-of-human-poverty-and-thebiodiversity-hotspots [last accessed 7 July, 2019]; see also https://books.google.com.ng/books? [ last accessed 7 July, 2019]

https://journals.openedition.org/sapiens/1452 [last accessed July 8, 2019]

I.U.C.N., 2004a

William M. Adams et al, Biodiversity Conservation and the Eradication of Poverty, Science 306 (5699) (2004), Pp. 1146-1149.

Available at https://www.cbd.int./doc/world/ng/-nr-01-en-pdf [last accessed 9 July, 2019]. See also First National Biodiversity Report, July 200.

See The National Bureau of Statistics Press Briefing by the Statistician-General of the Federation, Abuja, Monday 13 February, 2012Available at www.nigeriastat,gov,ng/-[last accessed 24 May 2019].

Also, according to the Human Development Index Report of United Nations Development Programme, the number of poor people in Nigeria remains high and the level of poverty is likely to increase over the years. See the United Nations Development Programme Report, 2008-2009.

9 https://www.pulse/news/local/nigeria-ends-2018-with-908-million-people-living-in-extreme-poverty-nljxqt? [Accessed 10 July, 2019].

10 https://qz.com/africa/1313380/nigerias-has-the-highest-rate-of-extreme-poverty-globally [last accessed 10 July, 2019]

11 Fatsuma. Olaleru, and Rosemary Egonmwan, Wildlife Conservation Challenges in Okomu National Park, Nigeria, Ethiopian Journal of Environmental Studies \& Management, 7(6), (2014), p. 670.

See Brundtland Report, 1987.

www.fao.org/3/T3660E/T3660E04.htm [Accessed 10 July, 2019]

Ibid

Isa Olalekan Elegbede et al, Wetland Resources of Nigeria: Case Study of the Hadejia-Nguru Wetlands, Poultry Fisheries \& Wildlife Sciences 2(2), (2014), Pp. 2-6. Available at https;//www.omicsonline.org/open-access/wetland-resources-of-nigeria-case-study-of-the- 
importance of wetlands, there is international commitment for its conservation and wise use ${ }^{1}$.

With the increased population witnessed in the recent time in Nigeria, reclamation of the wetlands is now a common practice in the country particularly in the cities without regard to its economic value ${ }^{2}$. As a show of concern, the Lagos State Government of Nigeria (Lagos is the economic focal point of Nigeria) has lamented the alarming rate at which wetlands and biodiversity are lost in the state as a result of indiscriminate destruction of natural habitats, reclamation for housing estate development and population expansion. ${ }^{3}$ This is also the situation in other major cities in Nigeria especially in the Niger delta region where wetlands have been reclaimed for other uses. Reports also suggested that multinational companies, exclusively those in the oil and gas sector, also reclaim wetlands for industrial use ${ }^{4}$. In coastal areas, mangroves have been converted to other land use thereby denied of its native plant and animal species. This trend promises to increase if the population explosion is overlooked without urgent action to arrest the situation.

\section{The Legal Frameworks for Population Control}

There is a concerted effort at international, regional and national levels to combat population explosion all over the world for sustainable development. This is because, if unchecked, it will outgrow the human means of subsistence on this planet called the 'Earth' and thus resulting to unimaginable crisis in terms of hunger, malnutrition and extreme poverty.

\section{(i) The Global Commitment}

The connection between population and the environment had been on the world-wide agenda as far back as the 1950s. Right from 1945 when the United Nations officially came into existence, several conferences on population have been held. In 1954, United Nations Educational, Scientific and Cultural Organization (UNESCO), an arm of the United Nations, convened world population conference in Rome and the idea that there are limits to the capacity of the earth to accommodate a growing population gained prominence at the international level ${ }^{5}$. The second conference was held in Belgrade in 1965. ${ }^{6}$ In 1974, another World Population Conference took place in Bucharest, Romania, from 19-30 August 1974. It was attended by representatives of 136 Member States. In that conference, a draft of the World Population Plan of Action was reviewed and adopted by the plenary. There was promotion of family planning by 59 Member States as a way of reducing the world growing population. ${ }^{7}$

To further agitate on world population control, in 1984, another World Conference on Population was convened in Mexico City between 6-4 August 1984. About 147 Member States out of 157 UN Member States then, participated at the Conference. In that Conference, out of the 147 Member States that attended the Conference, an increasing number of 123 countries promoted family planning. This is far more than the number of States that supported family planning in the hitherto 1965 Conference. This shows more awareness of the impact of human population growth on the environment. In that Conference unlike the position of some of the developing countries in the 1965 Conference, many developing countries including Nigeria expressed their unalloyed support for family planning and population programmes. ${ }^{8}$ Their position is simply to reduce the world growing population for sustainable development. Also, in 1994, another International Conference on Population and Development was held in Cairo, Egypt, from 5-13 September 1994. ${ }^{9}$ The Conference adopted the Programme of Action, which emphasized the fundamental role of women's interests in population matters and introduced the concepts of sexual and reproductive health and reproductive rights. All is geared towards reducing the world population to such level that the earth carrying capacity can endure for sustainable development. Furthermore, in 1999, a special session of the General Assembly, as a five-year review of the International Conference on Population and Development (ICPD) was held in New York to offer a clear and authoritative guide to future action, including mobilizing the resources imperative for implementation of the

hadejia-nguru-wetlands [last accessed 23 May, 2019].

See the International Convention on Wetlands of International Importance especially as Waterfowl Habitat (the "Ramsar Convention") 1971.

Ajibola, M. O., note 50, p. 311

K. Ugbodaga, "Lagos laments loss of wetlands, biodiversity", PM News, Tuesday 2 $2^{\text {nd }}$ October, 2018. Also available https://www.pmnewsnigeria.com/2017/09/22/lagos-laments-loss-of-wetlands-biodiversity[last accessed 2 June 2019].

4 Chidumeje Ndidi Patience Okonkwo, Lalit. Kumar and Subhashni. Taylor, The Niger Delta Wetland Ecosystem: What Threatens It and Why Should we protect it?, African Journal of Environmental Science and Technology, 9(5)(2015), Pp. 451-463. Available at www/academicjournals.org.journal.AJEST/article-full-text-pdf/2B3416852458 [last accessed 1 June, 2019].

5 William.M. Adams, Green Development Environment and Sustainability in a developing World, London 2007, Pp. 50-51. The whole idea is hinged on the international environmental principle of "carrying capacity". It means the maximum population size the earth can adequately sustain giving the available resources.

www.un.org/en/development/desa/population/events/conference/index.shtml [last accessed 15 June 2019]. Ibid

Ibid

It was attended by 179 governmental delegations from UN Member States, 7 observers at governmental level, the European Union and several hundred NGOs. Several thousand media representatives covered the Conference. 
Cairo Programme of Action on Population and Development. ${ }^{1}$

\section{(ii) Nigerian Experience}

In response to the several Population Conferences held across the world and Africa in the 1960s, 1970s, and the 1984 Conference in Arusha, Tanzania as a precursor to the second International Conference on Population in Mexico City 1984 to which Nigeria participated, the government of Nigeria formulated the nation's first population policy in 1988, titled "National Policy on Population for Development, Unity, Progress and Self Reliance. ${ }^{2}$ The Policy was designed “...to achieve lower population growth rates through reduction of birth rates by voluntary fertility regulation methods that are compatible with the attainment of economic and social goals of the nation..."3. It was viewed that the policy was an outcome of an intensive process of consultations and discussion covering different interest groups save for cultural groups. ${ }^{4}$ After the launching of the Policy, there was problem of implementation due to insufficient funds, poor coordination among the lead agencies and service providers and lack of political will. As a result of the perceived failure of the 1988 Population Policy, there was an urgent need to revise the Policy. In 2000, the then President of Nigeria, President Olusegun Obasanjo issued a mandate to streamline population management nationally. A committee was formed with the mandate to both review population policy and coordinate and monitor all population management activities. However, the management responsibilities were not transferred until 2003. ${ }^{5}$

In 2004, there was another National Policy on Population for Sustainable Development adopted in 2005. It is one of the cardinal aims of the Policy to address the complex interrelationships between population and development. To drive the implementation, the Strategic Plan for the National Population Policy for Sustainable Development was launched in 2008. Following a continued rapid population growth, in 2013, the National Population Commission and the Population Technical Working Group with support from the USAID developed a roadmap to guide the policy's implementation assessment and its revision. Significantly, there has been no attempt at all to enact a law for the regulation of the country's growing population despite its impact on the environment.

From the above discussions on the legal frameworks for population control both at the international arena and Nigerian experience, it is clear that what is available now for the control of population in the country is a mere policy on population control which admits without more a voluntary fertility regulation methods. The policy is a soft law and has not proven to be effective in controlling the ever increasing population size of the country. It has no force of law and cannot be enforced against any one in default as there is no sanction attached to it in event of default. Many parents are still having more than the proposed four children per family under the Nigeria Population Control Policy of 1988 probably because there are no incentives attached to the policy. There is therefore the urgent need to take a more stringent measure in controlling the population size of the country if we must cope with the present economic realities. It has been observed that religious and cultural beliefs continue to be a major impediment, but we cannot play the ostrich anymore; we must take the bull by the horns. ${ }^{6}$ The issue of population control as a measure for biodiversity conservation is too important to avoid just because it is controversial. ${ }^{7}$ Government at all levels must wake up to the challenges of population control for sustainable development and such a serious issue to be left at the discretion of couples to determine the number of children they should have, will not achieve more.

At the international arena, there is a clamour for a United Nations Framework Convention on Population Growth by the Population Media Center's President Bill Ryerson-one similar to the Paris Agreement for climate change with Nationally Determined Contributions (NDCs) in pursuit of a sustainable population in every country $^{8}$. Family planning and population management are generally not just life-saving interventions but actually critical tools for economic and social development. Hence, the need for a legal framework intervention.

\section{A Lesson from other Jurisdictions: Indian}

Virtually, all the countries of the world are suffering from the menace of population increase. However, the awareness and the need for population control is common all over the world but the challenge is in the area of implementation because most countries adopted the measure of family planning and the policy of two-child per

\footnotetext{
https://www.un.org/press/en/1998/19980224.POP660.html [last accessed 16 May 2019].

https://www.healthpolicyproject.com/pubs/821_FINALNPPReport.pdf [last accessed 15 May 2019].

3 Nigeria Population Policy, 1988.

Enang,Ebingha and Michael. Ushie, Cultural and Policy Implementation: An Appraisal of Population Policy in Nigeria, International Journal of Humanities and Social Science, 2(17) (2012), Pp. 226-229

See foot 96

Francis Eweherido, Nigeria's Exponential Population, Vanguard Newspaper, July 7, 2018. Available also at https://www.vanguardngr.com/2018/07/nigerias-exponential -population/ [last accessed 19 November 2018]

${ }^{7}$ It is a universal agitation that it is not the place of government to determine the number of children a family should have. In the religious circle, the Islamic religion promotes large families with the encouragement of early marriage and polygamous family system. The Christian religion in turn prohibits the most effective forms of contraceptives and most are anti-abortion. The two major religions advocate population growth without control.

8 https://mahb.stanford.edu/blog/un-framework-population / [last accessed 15 May 2019].
} 
family. ${ }^{1}$ Some nations have gone a step further; there are laws in some States that create dis-incentives if each couple has more than two children. Examples of these dis-incentives include refusal of government rights for the third, fourth and other number of children, denying health care for mothers and children, denying nutritional supplements for women pregnant with their third or more children, jail and fines for fathers, a general decrease in social services for large families, and restrictions on government position appointment and promotion. ${ }^{2}$

Notwithstanding the Indian government rejecting laws controlling population, as of 2014, 11 Indian States have passed laws to restrict Indian citizens from having more than two children. Under the law, people running for local government elections can be disqualified if they have not respected the two-child policy. The idea behind the law is that ordinary citizen will look up to their local politicians and follow their family size example. ${ }^{3}$ This is probably because the existing Indian policy on population control was no longer proving enough to control her ever increasing population and thus the need for a more stringent measure. Currently, there was fresh plea filed at the Supreme Court of Indian seeking a direction to the Centre to ensure strict population control measures by adopting a two-child policy. It also sought a direction to the Centre to take appropriate steps to make two-child norms a mandatory criterion for contesting parliamentary, state assembly and local body elections. $^{4}$

On the contrary, during the early days of Spain and France the reverse is the case. In Spain, a 1623 edict granted tax exemptions to couples that married at a young age and had large families. Also in France, a 1666 edict provided for tax exemptions for early marriage and pensions for fathers with at least ten legitimate children. ${ }^{5}$ This measure can be adopted in the opposite by enacting a law on population control thereby granting tax exemptions to families that have the number of restricted children as well as benefiting other social incentives as a means to encourage compliance.

\section{Conclusion}

It must be recognized that in this our finite world where resources are limited, man must reasonably balance the growing population with the carrying capacity of the earth. Population is an indirect cause of biodiversity loss and has been reinforcing other drivers of biodiversity loss such as habitat loss, deforestation, urbanization, poverty etc. Until there is a more strict measure other than mere policy on population control, the continuing loss of biodiversity in the country will be unabated and more will go into extinction. Integrating biodiversity conservation through family planning law is key for sustainable development. Biodiversity is an integral component of our life-support systems and thus plays a crucial role in the sustainable development. It suffices to say that the role of biological diversity in achieving sustainable development cannot be over-emphasized. For we all depend on the environment for human well-being and ecosystems services. A controlled population size means a healthier environment for our survival. If the environment cannot sustain the growing population, the more danger it portends for us and worst for the future generations. In appreciating the role of biological diversity for sustainable development of any country, a Norwagian Minister of Finance observed as follows:

Attention to biological diversity and natural resources are essential to achieve a sustainable development. Protecting this diversity is not only important in itself but also a base for economic activity. In my opinion, this is not only the case for Norway, but for countries... The way I see it, biological diversity is necessary to achieve a greater goal, a development that is socially and economically sustainable, within the boundaries of healthy ecosystems. Sustainable development should be given attention in Governments' work in all areas. It should not be seen only as relevant to environment ministers. Many of the challenges to overall sustainability are really about how to combine economic and social development with viable ecosystems... ${ }^{6}$

For examples, in China, as far back as 1979, the country instituted one-child per family policy. But in 2015, the government allowed married couples to have two children. In United Kingdom, there is a recent move for two-child policy as a way to combat population increase and climate change. In fact, the two-child policy took effect in 2017 . The policy excludes all but the first two children from all available benefits; an exemption can be applied if the conception of the third and any further children occurred as result of the rape of the claimant. In Vietnam, the population control policy was launched as far back as 1960s and continues in a modified form today. The policy emphasizes the official family size of "one or two children". Also, in Singapore, the policy was launched long ago and called "Stop at two". See https://en.wikipedia.org/wiki.Two-child-policy [last accessed 19 May 2019].

https//leadership.ng/2017/08/18/controlling-population-nigeria [last accessed 16 May 2019].

https://www.investopedia.com/articles/personal-finance/051415/indias-two-child [last accessed 16 May 2019].

https//timessofindia.indiatimes.com/india/fresh-plea-in-sc-on-population-control [last accessed 19 May 2019].

5 Barry Mirkin, Evolution of national Population Policies since the United Nations 1954 World Population Conference, JSTOR, 61 (3-4) (2005), p. 297.

${ }^{6}$ See the Speech by the Norwagian Minister of Finance, Mr. Sigbjorn John, titled "Biological Diversity, Sustainable Development and the Economy" at the seminar 'Getting the Biodiversity Targets Right-Working for Sustainable Development' held at Trondheim on the $5^{\text {th }}$ of February, 2010. 


\section{Recommendations}

- The Government should take a proactive step further to enact law on population control that would regulate the family size of every household and adopting both incentive and dis-incentive measures as applicable in other jurisdictions. This is necessary because the various Population Policies of Nigeria are mere soft laws without enforceable right and have been violated without the necessary sanction.

- Carrying out population education awareness to sensitize married couples about the issue of existing human overpopulation, continued growth, including why it poses an existential threat and why embracing small family size is an essential component for a healthy living and human wellbeing.

- Government should prioritize the ease of access model of fertility decline, which appears to fit the country's situation.

- Institutional mechanisms should also be put in place to ensure implementation and compliance to the law so as to achieve the needed objectives. 